\title{
Assessment of Anthropogenic Activities on Water Quality of Benin River
}

\section{*AYOBAHAN, SU:, ${ }^{1}$ EZENWA, IM:, ${ }^{1}$ OROGUN, EE:, ${ }^{1}$ URIRI, JE:, ${ }^{1}$ WEMIMO, IJ}

\footnotetext{
*Department of Environmental Management \& Toxicology, Faculty of Life Sciences, University of Benin, Nigeria

${ }^{1}$ Department of Animal and Environmental Biology, Faculty of Life Sciences, University of Benin, Nigeria

*Corresponding author e-mail: ayobahan@uniben.edu
}

KEY WORDS: Organic pollution, Industrial effluent, Water Quality Index (WQI), Principal Component Analysis (PCA).

\begin{abstract}
Assessment of water quality was conducted from June to December, 2011 in five stations along the stretch of the Benin River between Ajimele and Koko town in attempt to assess and determine the source of anthropogenic activities affecting the river. Twentyfour parameters have been monitored on 5 sampling stations on a monthly-day-trip. Inter station comparisons and locations of significant differences were carried out using parametric ANOVA and Duncan multiple range tests. Principal Component Analysis (PCA) and Water Quality Index (WQI) were used to establish relationship among water quality parameters and determine the water quality status. First six components of PCA accounted for $90.96 \%$ of observed variations and showed similarity between the sampling stations indicating different anthropogenic activities and pollution levels of sampled sites. Factors identified as responsible for variability in the sampling stations are organic pollution, industrial effluent, soil erosion, nutrient loading and human activities, especially in station 4 and 5. WQI for sampling stations 1 and 3 was very poor for drinking (201 - 300) and stations 2,4 and 5 was unsuitable (> 301) for human consumptions. In the final analysis, this investigation presents the usefulness of PCA and WQI in assessing complex datasets of surface water quality and as well as a call to action for the state and federal ministry of environment to take this issue of water quality degradation in Benin River into consideration, by reducing organic pollution and effluent discharge into the river. An intense and continuous water quality monitoring is highly recommended. @ JASEM
\end{abstract}

http://dx.doi.org/10.4314/jasem.v18i4.11

\section{Introduction}

Rivers are the most important freshwater resource for man. Apart from its function as a source of freshwater for drinking, domestic and industrial uses; freshwater resources serve multiple functions most of them being critical to human settlement and survival. Polluted water is an important vehicle for the spread of diseases. Adequate supply of safe and sanitised freshwater is an inevitable factor for human and economic development. Reports by Food and Agricultural Organisation (FAO) revealed that in African countries, particularly Nigeria, water related diseases had been interfering with basic human development (FAO, 2007). The common sources of water that are available to local communities in Nigeria are fast being severed by a number of anthropogenic factors, of which pollution remain the most dominant problem. Water abstraction for domestic use, agricultural production, mining, industrial production, power generation, and forestry practices can lead to deterioration in water quality and quantity that impact not only the aquatic ecosystem, but also the availability of safe water for human consumption (UNEP, 2006).

Until recently, multivariate analysis like principal component analysis has not been widely used, largely due to the massive computation capacity required. The availability of faster and cheaper hardware and software in computers is now enabling us to apply this set of statistical methods to environmental data (Anazawa et al., 2004). Water Quality Index (WQI) is an efficient tool use for classifying the suitability of water resource. Over the years, WQI has evolved as an efficient tool use in summarising water quality data into simple terms for water resource managers (Ashwani, and Anish, 2009). It evaluates the overall quality of water using an established standard and further predicts if water quality poses a potential threat to habitat for aquatic life, irrigation water for agriculture and livestock, recreation and aesthetics and drinking water supplies. 
Benin River in Southern Nigeria, like any other rivers in developing countries serves as a reservoir for both industrial and domestic wastes. The river is a large body of water that flows through so many communities in the Niger-Delta coast. As a result it experiences eutrophication, acidification, sediment inflow consisting of organics and trace metals arising from hydrocarbon activities. In spite of the heavy load of pollutants in the surface water of the river, majority of the populace and industries close to the river depends on the water for both domestic and industrial uses.

The aim of this study is to augment the already existing data base on physical and chemical characteristics of the surface water and further adopt an index and multivariate approaches in assessing the impact of anthropogenic activities on the physical and chemical characteristics of Benin River. The specific objectives include: characterizing the status and the spatial variability of the physical and chemical characteristics of certain stretch of Benin River; to predict the principle parameters responsible for variability in the physico-chemical parameter of the river and assess the quality of the water for consumption and domestic purposes using water quality index (WQI).

\section{STUDY AREA}

The study was conducted along certain stretch of Benin River situated in the north central part of Delta State (Latitudes 05054'14.9" - 05 $59^{\prime} 54.9^{\prime \prime} \mathrm{N}$; Longitude $005^{\circ} 41^{\prime} 50.7^{\prime \prime}-005^{\circ} 27^{\prime} 006 " \mathrm{E}$ ) (Figure 1). The stretch of the study area is approximately 30.62 $\mathrm{km}$ long and the rivers flows through a mangrove swamp forest. Three distinct longitudinal zones could be recognized in this river, the upper freshwater zone, the middle transitional zone with salinity fluctuations and the lower coastal zone which is predominately saline. The present study was conducted in its upper fresh water reaches in commercial town of Sapele and Koko town. Five stations were distinguished along the study stretch.

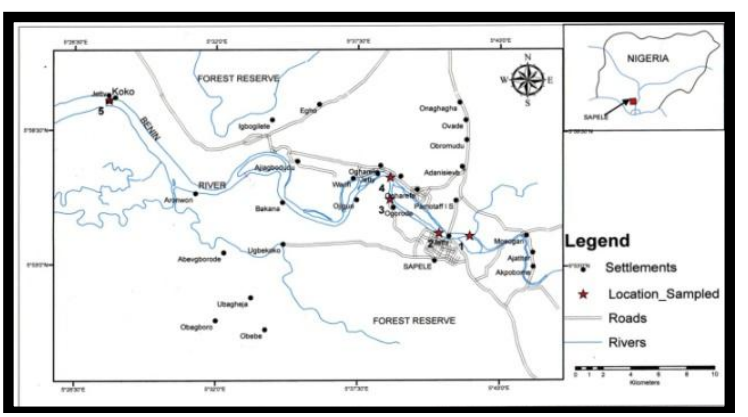

Fig. 1 Map of Study Area indicating sampling locations

\section{MATERIALS AND METHODS}

The samplings were conducted monthly from June to December, 2011, covering rainy and part of dry seasons. On each occasion, samples for physicochemical parameters were collected between 1000 and $1600 \mathrm{hr}$ at all stations. Water temperature, $\mathrm{pH}$, TDS and EC were determined in-situ using Extech meter probes (Exstik II). The surface-float method was used to measure current velocity. Water Turbidity, phosphate, sulphate were determined using spectronic 2ID spectrophotometer (APHA, 1998). COD were determined using titrimetry method, chloride was determined by Mohr's method (APHA, 1998) and nitrate was determined by colorimetric method. Technicon auto analyzer flame photometer (IV) was used in determination of Sodium and potassium while calcium and magnesium were determined by EDTA titrimetery method (APHA, 1998). Heavy or trace metals were determined after digestion of the solution of the samples using Pye Unican SP Atomic Absorption Spectrometry. The essence of the digestion before analysis was to reduce organic matter interference and convert metal to a form that can be analyzed by Atomic Absorption Spectrometry (Chinedu, et al., 2011).

Data Analysis: Analysis of Variance (ANOVA) and Principle Component Analysis (PCA) Inter station comparisons were carried out to test for significant differences in the physicochemical conditions using parametric ANOVA. If significant value $(\mathrm{P}<0.05)$ were obtained in ANOVA, Duncan multiple range test was performed to determine the location of significant differences. PCA was applied to summarize the statistical correlation among the parameters and further identify the parameters among which were analyzed that play significant roles in variations within this sampling stations.

The principal component (PC) is expressed as:

$$
\begin{aligned}
P C_{a b}=Z_{a 1} K_{1 b} & +Z_{a 2} K_{2 b} \cdots \\
& +Z_{a i} K_{i b} \cdots
\end{aligned}
$$

Where $P C$ is the component score, $\mathrm{Z}$ is the component loading, $a$ is the component number and $b$ is the sample number. The varimax rotation of the generated PC results can readily be interpreted. Varimax factor correlation coefficient of $>0.75,0.74$ 0.50 and $0.49-0.30$ are considered as strong, moderate and weak factor loading respectively (Liu et al., 2003).

Water Quality Index (WQI) for surface water: In this study, WQI was calculated by using the Weighted Arithmetic Index method as described by (Cude, 2001) (Table 1). In this model, different water quality components are multiplied by a weighting factor and are then aggregated using simple arithmetic mean. 
For assessing the quality of water in this study, firstly, the quality rating scale $\left(\mathrm{Q}_{\mathrm{j}}\right)$ for each parameter was calculated by using the following equation;

$$
Q_{i}=\frac{\Delta \beta_{0}}{\Delta \beta_{1}} * 100
$$

Where, $Q_{i}$ is quality rating, $\beta_{0}$ is change in measured value from idea value and $\beta_{1}$ is difference in the ideal value from standard of that water quality for ith parameter. The $\beta$ ideal for $\mathrm{pH}$ is $7, \beta$ ideal for dissolved oxygen is $14.6 \mathrm{mg} / \mathrm{L}$ and other parameters is equal to zero and $\beta$ standard is Recommended Nigerian Standard for Drinking Water Quality (NIS, 2007) and World Health Organization Standard/Guideline Value (2004). The Relative (unit) weight (Wi) was estimated by a value inversely proportional to the recommended standard (Ki) for the corresponding parameter using the following expression;

$$
W_{i}=\frac{1}{K i}
$$

Where, $\mathrm{W}_{\mathrm{i}}$ is Relative (unit) weight and $\mathrm{K}_{\mathrm{i}}$ is the Standard permissible value for ith parameter. The WQI was obtained by aggregating the quality rating with the unit weight linearly by using the following equation:

$$
W Q I=\sum \frac{W i Q i}{W i} \quad \ldots .(\text { eqn } 4)
$$

Table 1: Classes of surface water quality using the WQI

\begin{tabular}{ll}
\hline WQI Levels & Description \\
\hline $\mathbf{0 - 1 0 0}$ & Suitable for drinking \\
$\mathbf{1 0 1}-\mathbf{2 0 0}$ & Poor for drinking \\
$\mathbf{2 0 1}-\mathbf{3 0 0}$ & Very poor for drinking \\
$>\mathbf{3 0 1}$ & Unsuitable for drinking \\
\hline
\end{tabular}

\section{RESULTS AND DISCUSSION}

Water quality of surface water: The surface water of Benin River is slightly acidic and the recorded $\mathrm{pH}$ showed no significant difference $(\mathrm{P}>0.05)$ among the stations (Table 2). Water temperatures, turbidity, BOD and DO also showed no significant difference (P>0.05) among the stations. TDS, TSS, TS, EC and COD of the river exhibited a highly significant difference $(\mathrm{P}<0.01)$ among the stations. A posteriori DMR test revealed that the level of EC observed at stations 4 and 5 were not significantly different from each other but were significantly higher than level observed at stations 1, 2 and 3. The level of EC observed at stations 1, 2, and 3 were not significantly different from one another. Spatial variations in the concentrations in TDS and TS were as observed in EC. In the case of TSS and COD, A posterior DMR test revealed that the level of these individual parameters observed at station 4 was significantly higher than the levels observed at stations 1, 2, 3 and 5 which were not significantly different from one another. Spatially, chloride and phosphate concentrations of the river showed a highly significant difference $(\mathrm{P}<0.01)$; for both parameters, A posterior DMR test revealed the same pattern of spatial variations as observed in EC. No significant difference $(\mathrm{P}>0.05)$ was observed in concentration of nitrate and sulphate among the stations. With exception of chromium, the concentrations of heavy metals showed significant difference $(\mathrm{P}<0.05)$ among the stations. A posteriori DMR test revealed the same pattern of spatial variations in concentrations as observed in EC for the heavy metals except manganese. A posteriori DMR test revealed that the concentration of manganese observed at station 5 was significantly higher than the concentrations observed at stations 1, 2, 3 and 4 which in turn were not significantly different from one another.

Principal Component Analysis (PCA): PCA was applied on the water quality parameters from the sampled stations to identify the species and factors that contribute to source of pollution in Benin River. Six rotated varimax loading factors were determined base on eigenvalues greater than 1 , as shown in Table 3. First six components of principle component analysis accounted for $90.96 \%$ of the observed variations in the water quality. The component PC1 represent $39.98 \%$ of variability which indicate a strong positive loading factor on TSS, COD, PO4 ${ }^{3-}$, $\mathrm{Na}, \mathrm{K}, \mathrm{Ca}, \mathrm{Mg}, \mathrm{Ni}$ and moderate loading on TS, Zn and $\mathrm{Pb}$. PC2 with $23.54 \%$ of variance designates a strong loading factor on EC, TDS, Fe, Cr, Mn and moderate $\mathrm{Cl}^{-}$. PC3 represent $11.68 \%$ of variability shows strong loading factor on $\mathrm{NO}_{3}{ }^{-}$and $\mathrm{SO}_{4}{ }^{2-}$ while the component PC4 $(6.43 \%$ of variance $)$ reflect strong loading factor on BOD and moderate DO. PC5 represent $4.95 \%$ of variation reflects a strong negative loading factor for $\mathrm{pH}$. Similarly component PC6 (4.46\% of variance) indicates strong loading factor of Turbidity. Considering the larger variability, the graph for two main principal components of $72 \%$ variability (PC1 57.3\%; PC2 14.7\%) of the total variance were plotted to explain sampled stations with high anthropogenic impact (Figure 2). 


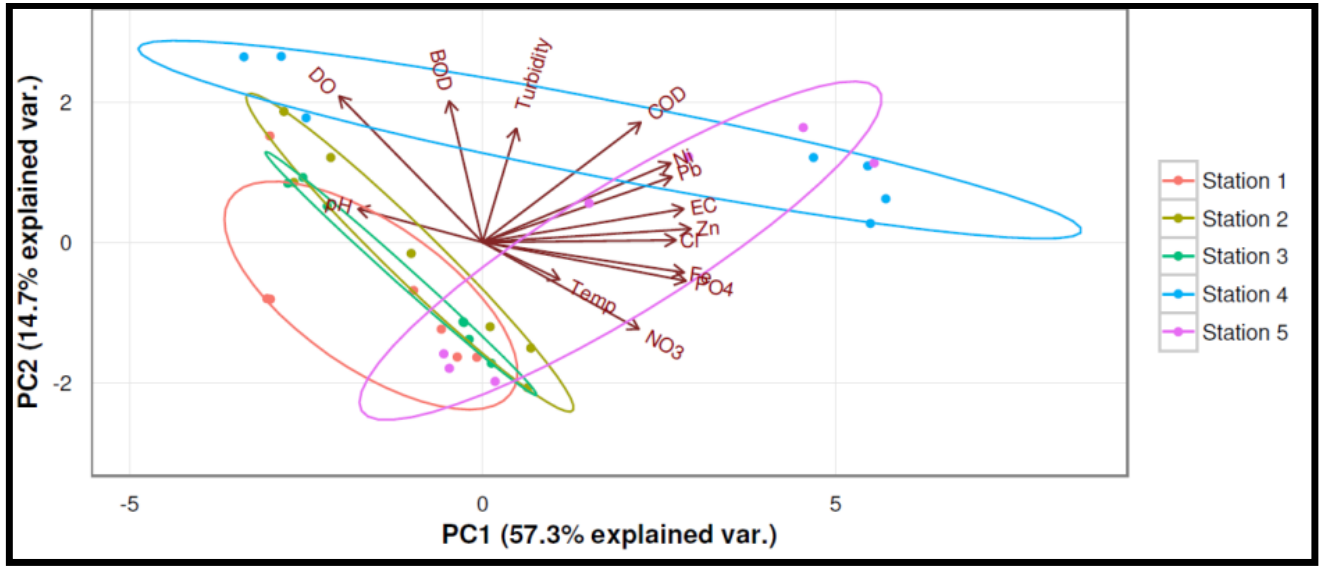

Fig.2: Principal components of water quality variability across sampling stations

Water quality index of sampling stations: The cumulative water quality index (WQI) observed in sampling station 1,2 and 3 were $234.45,315.26$ and 295.09 respectively (Table 2 ). On the contrary, a drastic increase in WQI was recorded in station 4 and
5 and the mean values were 1710.49 and 1421.06 (Figure 3). Monthly variability of WQI showed high value in October (3075.36) and July (3862.31) for station 4 and 5 respectively.

Table 2: Summary of the WQI computations across the stations

\begin{tabular}{llllll}
\hline & Station 1 & Station 2 & Station 3 & Station 4 & Station 5 \\
\hline Wi & 181.64 & 181.64 & 181.64 & 181.64 & 181.64 \\
WiQi & 42585.07 & 57263.06 & 53699.90 & 310693.73 & 258121.85 \\
WQI & 234.45 & 315.26 & 295.09 & 1710.49 & 1421.06 \\
\hline
\end{tabular}

Table 3: Summary of physical and chemical characteristics of surface water from Benin River

\begin{tabular}{|c|c|c|c|c|c|c|c|}
\hline & Station 1 & Station 2 & Station 3 & Station 4 & Station 5 & & $\begin{array}{l}\text { NIS } \\
(2007) \text { \&WHO } \\
\text { Standard }\end{array}$ \\
\hline Parameters $(n=7)$ & $\bar{x} \pm$ SD & $\bar{x} \pm$ SD & $\bar{x} \pm$ SD & $\bar{x} \pm$ SD & $\bar{x} \pm$ SD & P-value & \\
\hline Water Temp $\left({ }^{0} \mathrm{C}\right)$ & $29.40 \pm 0.96$ & $29.89 \pm 0.90$ & $29.89 \pm 1.04$ & $30.60 \pm 1.56$ & $30 . \overline{40} \pm 1.00$ & $\mathrm{P}>0.05$ & 27 \\
\hline $\mathrm{pH}$ & $5.80 \pm 0.18$ & $5.77 \pm 0.40$ & $5.80 \pm 0.15$ & $5.61 \pm 0.22$ & $5.69 \pm 0.13$ & $\mathrm{P}>0.05$ & $6.5-8.5$ \\
\hline TDS (mg/l) & $22.21 \pm 6.95^{\mathrm{B}}$ & $25.86 \pm 9.25^{\mathrm{B}}$ & $25.14 \pm 6.11^{\mathrm{B}}$ & $186 . \overline{93} \pm 162.92^{\mathrm{A}}$ & $249 . \overline{57} \pm 198.18^{\mathrm{A}}$ & $\mathrm{P}<0.01$ & 500 \\
\hline TSS (mg/1) & $9.55 \pm 2.94^{\mathrm{B}}$ & $11.35 \pm 3.51^{\mathrm{B}}$ & $11.02 \pm 2.20^{\mathrm{B}}$ & $79.33 \pm 67.42^{\mathrm{A}}$ & $36.89 \pm 51.56^{\mathrm{B}}$ & $\mathrm{P}<0.01$ & N/A \\
\hline $\mathrm{TS}(\mathrm{mg} / \mathrm{l})$ & $31.84 \pm 9.58^{\text {В }}$ & $37.20 \pm 12.58^{\mathrm{B}}$ & $36.16 \pm 8.22^{\mathrm{B}}$ & $266.26 \pm 230.34^{\mathrm{A}}$ & $286.46 \pm 217.95^{\mathrm{A}}$ & $\mathrm{P}<0.01$ & N/A \\
\hline Turbidity (NTU) & $4.68 \pm 0.55$ & $5.62 \pm 0.52$ & $5.21 \pm 0.72$ & $6.11 \pm 0.90$ & $4.33 \pm 3.32$ & $\mathrm{P}>0.05$ & 5 \\
\hline $\mathrm{EC}(\mu \mathrm{S} / \mathrm{cm})$ & $44.29 \pm 14.19^{\mathrm{B}}$ & $51.71 \pm 18.49^{\mathrm{B}}$ & $50.29 \pm 12.23^{\text {в }}$ & $373.86 \pm 325.85^{\mathrm{A}}$ & $499.14 \pm 396.37^{\mathrm{A}}$ & $\mathrm{P}<0.01$ & 1000 \\
\hline DO (mg/l & $6.25 \pm 0.74$ & $6.52 \pm 0.95$ & $6.27 \pm 0.49$ & $6.63 \pm 1.26$ & $5.93 \pm 0.16$ & $\mathrm{P}>0.05$ & N/A \\
\hline BOD (mg/l) & $2.78 \pm 0.48$ & $3.02 \pm 0.34$ & $2.94 \pm 0.18$ & $3.58 \pm 1.06$ & $3.34 \pm 0.60$ & $\mathrm{P}>0.05$ & N/A \\
\hline $\mathrm{COD}(\mathrm{mg} / \mathrm{l})$ & $19.14 \pm 5.69^{\mathrm{B}}$ & $24.18 \pm 7.41^{\text {B }}$ & $22.18 \pm 6.73^{\mathrm{B}}$ & $115.65 \pm 77.70^{\mathrm{A}}$ & $61.05 \pm 65.37^{\mathrm{B}}$ & $\mathrm{P}<0.01$ & N/A \\
\hline $\mathrm{Cl}^{-}(\mathrm{mg} / \mathrm{l})$ & $11.93 \pm 5.90^{\mathrm{B}}$ & $14.21 \pm 7.15^{\mathrm{B}}$ & $12.43 \pm 7.35^{\mathrm{B}}$ & $111.00 \pm 99.18^{\mathrm{A}}$ & $134.41 \pm 110.89^{\mathrm{A}}$ & $\mathrm{P}<0.01$ & 200 \\
\hline $\mathrm{NO}_{3}{ }^{-}(\mathrm{mg} / \mathrm{l})$ & $0.98 \pm 0.86$ & $1.18 \pm 1.02$ & $1.08 \pm 0.90$ & $1.12 \pm 0.98$ & $0.93 \pm 0.74$ & $\mathrm{P}>0.05$ & 50 \\
\hline $\mathrm{PO}_{4}{ }^{3-}(\mathrm{mg} / \mathrm{l})$ & $0.17 \pm 0.14^{\text {В }}$ & $0.20 \pm 0.16^{\mathrm{B}}$ & $0.19 \pm 0.14^{\mathrm{B}}$ & $1.82 \pm 1.69^{\mathrm{A}}$ & $1.21 \pm 1.17^{\mathrm{A}}$ & $\mathrm{P}<0.01$ & N/A \\
\hline $\mathrm{SO}_{4}{ }^{2-}(\mathrm{mg} / \mathrm{l})$ & $1.64 \pm 1.42$ & $1.96 \pm 1.69$ & $1.80 \pm 1.50$ & $2.59 \pm 2.31$ & $2.00 \pm 1.85$ & $\mathrm{P}>0.05$ & 100 \\
\hline $\mathrm{Na}(\mathrm{mg} / \mathrm{l})$ & $2.21 \pm 1.41^{\mathrm{B}}$ & $2.61 \pm 1.71^{\mathrm{B}}$ & $2.44 \pm 1.46^{\mathrm{B}}$ & $40.14 \pm 37.07^{\mathrm{A}}$ & $16.74 \pm 28.59^{\mathrm{B}}$ & $\mathrm{P}<0.01$ & 200 \\
\hline $\mathrm{K}(\mathrm{mg} / \mathrm{l})$ & $2.94 \pm 1.49^{\mathrm{B}}$ & $3.48 \pm 1.83^{\mathrm{B}}$ & $3.32 \pm 1.44^{\mathrm{B}}$ & $49.95 \pm 45.73^{\mathrm{A}}$ & $20.77 \pm 35.45^{\text {В }}$ & $\mathrm{P}<0.01$ & N/A \\
\hline $\mathrm{Ca}(\mathrm{mg} / \mathrm{l})$ & $0.73 \pm 0.54$ & $0.88 \pm 0.65$ & $0.81 \pm 0.56$ & $2.64 \pm 2.33$ & $1.35 \pm 1.74$ & $\mathrm{P}>0.05$ & N/A \\
\hline $\mathrm{Mg}(\mathrm{mg} / \mathrm{l})$ & $1.40 \pm 1.10$ & $1.66 \pm 1.32$ & $1.53 \pm 1.16$ & $4.09 \pm 3.61$ & $2.20 \pm 2.60$ & $\mathrm{P}>0.05$ & 20 \\
\hline $\mathrm{Fe}(\mathrm{mg} / \mathrm{l})$ & $0.52 \pm 0.39^{\mathrm{B}}$ & $0.62 \pm 0.47^{\mathrm{B}}$ & $0.58 \pm 0.40^{\mathrm{B}}$ & $2.62 \pm 2.36^{\mathrm{A}}$ & $2.51 \pm 2.47^{\mathrm{A}}$ & $\mathrm{P}<0.05$ & 3.0 \\
\hline $\mathrm{Cr}(\mathrm{mg} / \mathrm{l})$ & $0.08 \pm 0.02$ & $0.09 \pm 0.03$ & $0.09 \pm 0.02$ & $0.32 \pm 0.25$ & $0.90 \pm 1.34$ & $\mathrm{P}>0.05$ & 0.05 \\
\hline $\mathrm{Zn}(\mathrm{mg} / \mathrm{l})$ & $0.17 \pm 0.07^{\mathrm{B}}$ & $0.20 \pm 0.09^{\mathrm{B}}$ & $0.19 \pm 0.06^{\mathrm{B}}$ & $1.49 \pm 1.31^{\mathrm{A}}$ & $1.35 \pm 1.76^{\mathrm{A}}$ & $\mathrm{P}<0.05$ & 3.0 \\
\hline $\operatorname{Mn}(\mathrm{mg} / \mathrm{l})$ & $0.07 \pm 0.01^{\mathrm{B}}$ & $0.09 \pm 0.01^{\mathrm{B}}$ & $0.09 \pm 0.02^{\mathrm{B}}$ & $0.47 \pm 0.36^{\mathrm{B}}$ & $1.51 \pm 1.89^{\mathrm{A}}$ & $\mathrm{P}<0.05$ & 0.10 \\
\hline $\mathrm{Pb}(\mathrm{mg} / \mathrm{l})$ & $0.02 \pm 0.00^{\mathrm{B}}$ & $0.03 \pm 0.00^{\mathrm{B}}$ & $0.03 \pm 0.00^{\mathrm{B}}$ & $0.19 \pm 0.15^{\mathrm{A}}$ & $0.15 \pm 0.19^{\mathrm{A}}$ & $\mathrm{P}<0.05$ & 0.01 \\
\hline $\mathrm{Ni}(\mathrm{mg} / \mathrm{l})$ & $0.06 \pm 0.00^{\mathrm{B}}$ & $0.07 \pm 0.01^{\mathrm{B}}$ & $0.07 \pm 0.01^{\mathrm{B}}$ & $0.40 \pm 0.31^{\mathrm{A}}$ & $0.23 \pm 0.25^{\mathrm{A}}$ & $\mathrm{P}<0.01$ & 0.02 \\
\hline
\end{tabular}

${ }^{A-B}$ Means with the same superscript in the same row are not significantly different 
Table 3: Varimax rotated matrix of water quality data shows eigenvalue, cumulative proportion and variability

\begin{tabular}{|c|c|c|c|c|c|c|}
\hline Parameter & PC1 & PC2 & PC3 & PC4 & PC5 & PC6 \\
\hline Temperature & 0.211 & -0.026 & 0.139 & -0.030 & 0.232 & -0.168 \\
\hline pH & -0.315 & -0.155 & -0.139 & 0.112 & -0.914 & -0.031 \\
\hline EC & 0.538 & 0.751 & 0.143 & 0.040 & 0.086 & 0.107 \\
\hline TDS & 0.538 & 0.751 & 0.143 & 0.039 & 0.086 & 0.107 \\
\hline TSS & 0.957 & 0.146 & 0.182 & -0.091 & 0.118 & 0.041 \\
\hline TS & 0.677 & 0.647 & 0.162 & 0.009 & 0.099 & 0.097 \\
\hline Turbidity & 0.271 & 0.283 & 0.068 & 0.196 & -0.004 & 0.892 \\
\hline DO & -0.170 & -0.271 & -0.508 & 0.717 & -0.251 & 0.205 \\
\hline BOD & -0.164 & 0.244 & -0.171 & 0.837 & -0.037 & 0.082 \\
\hline COD & 0.954 & 0.225 & 0.068 & -0.019 & 0.100 & 0.126 \\
\hline $\mathrm{Cl}^{-}$ & 0.592 & 0.736 & 0.149 & 0.011 & 0.077 & 0.092 \\
\hline $\mathrm{NO}_{3}^{-}$ & 0.262 & 0.176 & 0.911 & -0.176 & 0.150 & 0.087 \\
\hline $\mathrm{PO}_{4}{ }^{3-}$ & 0.887 & 0.364 & 0.221 & -0.082 & 0.122 & 0.035 \\
\hline $\mathrm{SO}_{4}{ }^{2-}$ & 0.462 & 0.131 & 0.818 & -0.154 & 0.137 & 0.089 \\
\hline $\mathrm{Na}$ & 0.963 & 0.107 & 0.175 & -0.109 & 0.116 & 0.007 \\
\hline $\mathbf{K}$ & 0.965 & 0.104 & 0.170 & -0.108 & 0.114 & 0.009 \\
\hline $\mathrm{Ca}$ & 0.857 & 0.152 & 0.427 & -0.149 & 0.131 & 0.050 \\
\hline Mg & 0.807 & 0.130 & 0.531 & -0.156 & 0.146 & 0.050 \\
\hline $\mathrm{Fe}$ & 0.576 & 0.754 & 0.250 & -0.034 & 0.120 & 0.086 \\
\hline $\mathrm{Cr}$ & 0.036 & 0.974 & -0.006 & 0.066 & 0.046 & 0.092 \\
\hline Zn & 0.644 & 0.590 & 0.107 & -0.050 & 0.054 & 0.074 \\
\hline Mn & 0.053 & 0.987 & -0.020 & -0.910 & 0.038 & 0.101 \\
\hline $\mathbf{P b}$ & 0.736 & 0.492 & 0.085 & -0.049 & 0.053 & 0.098 \\
\hline $\mathrm{Ni}$ & 0.925 & 0.321 & 0.115 & -0.067 & 0.107 & 0.091 \\
\hline Eigenvalue & 9.964 & $5.885^{-}$ & $2.921^{-}$ & $1.585^{-}$ & $1.239^{-}$ & 1.114 \\
\hline Proportion of Variance $(\%)$ & 39.986 & 23.541 & 11.683 & 6.342 & 4.954 & 4.456 \\
\hline Cumulative Proportion (\%) & 39.986 & 6.339 & 7.508 & 8.142 & 8.637 & 9.083 \\
\hline
\end{tabular}

Water Quality Index

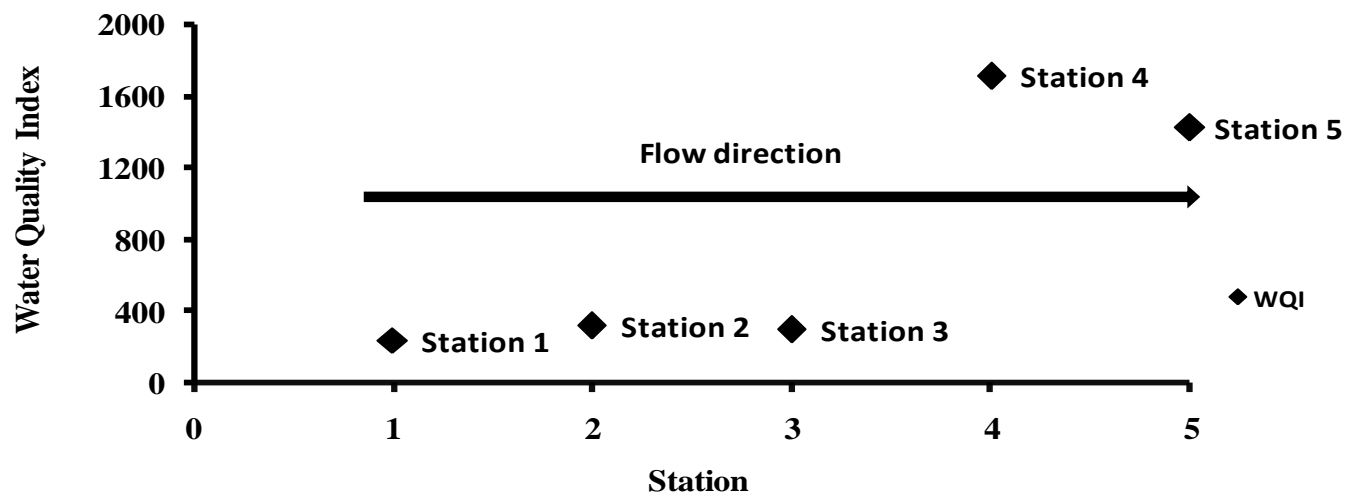

Fig. 3: Cumulative Water Quality Index at the sampling stations of Benin River.

Water quality of surface water: The water temperatures obtained in this study were similar among the stations throughout the duration of this study. No sudden rise in water temperature was observed throughout the study duration especially at stations. The slight rise in water temperature observed at station 4 may be attributed to intense human activities going on upstream and natural processes. The observed $\mathrm{pH}$ values are similar to the values obtained by Kaizer and Osakwe (2010). Low pH of the river indicates poor buffering capacity of total alkalinity and may also be as a result of organic matter decomposition. The conductivity of the river is dissimilar among the stations and increases downstream. The observed conductivity in this study is quite higher especially at stations 4 and 5; when compared with other stations upstream may be as a result of the industrial activities at the watershed and human activities going on upstream. The high TSS values and variation at this station may be attributed to the proximity of the station to residential quarter, action of rain encountered mostly during the sampling period, lumbering and industrial activities. Highest TSS value observed at station 4 are attributable to sand mining and semi-intense industrial activities; abattoir and market 
going on upstream (Oghareki) which use the river as the waste disposal site. TSS decrease water transparency, inhibits photosynthesis, increase of bottom sediments, and smothers aquatic organism breeding bed (Ogbeibu and Anagboso, 2003/04).

Dissolved oxygen is an important indicator of water quality, ecological status, productivity and health of a river (Moshood, 2008). The dissolved oxygen values obtained during sampling fluctuated between 5.36 and 8.42. The presence of organic pollutants in water majorly through human activities decrease dissolved oxygen while increasing the biochemical oxygen demand. The values of Biochemical Oxygen Demand $\left(\mathrm{BOD}_{5}\right)$ from the various sampled stations range from 2.78-3.58 $\mathrm{mg} / \mathrm{l}$. The possible reason for difference observed between the ranges obtained in this study is increase in anthropogenic activities in the river and its shed which in turn can directly or indirectly increase use of the river as waste receptacle. Films of oil were observed at the water surface especially at stations 2, 4 and 5 this hinders re-aeration at water surface thus reduces dissolved oxygen concentration while increasing the biochemical oxygen demand because it is organic in nature. A river can self-purify itself if the BOD is below 4mg/l (Radojevic and Bashkin, 1999) and the difference observed between stations 2 and 3 is attributed to self purification ability of the river. The least and highest mean concentration of chemical oxygen demand (COD) was observed at stations 1 and 4 respectively. The high level of substances which can be oxidized chemically observed at station 4 is an evidence of the intense anthropogenic activities going on both in the river and watershed at and upstream of that station. High COD has been linked with pollution (Tepe et al., 2005). Lesser value observed at station 3 when compared to station 2 probably resulted from the flowing current which increased downstream. The infrequent observations obtained in terms of COD concentrations can be attributed to pollution especially by organic matter.

Heavy metals have been used as indicator of pollution because of their high toxicity to human and aquatic life (Omoigberale and Ogbeibu, 2005). Egborge (1991), Ezemonye (1992) and Edema (1993) have linked the high concentrations of heavy metals in the aquatic ecosystems with effluents from industries, refuse and sewage. The concentrations of iron observed at all stations except 4 and 5 were low $(>1.5 \mathrm{mg} / \mathrm{l})$. Higher concentration of iron observed at station 2 when compared to that of station 3 can be attributed to abattoir wastewater containing blood which is being discharged at the station. The same case is applicable at station 4 and 5, though industries are being located along one of the banks at station 4 , an abattoir is located upstream which will also can be contributing to the iron load. The concentration of chromium obtained especially at station 1, 2 and 3 are similar to what was observed in a baseline study of Utor River by Ogbeibu and Anagboso (2003/04). The level of zinc observed at station 1 - 3 is similar to observation made by Aisien et al. (2010) in their study of the same river earlier. Like in the case of chromium, high concentrations of zinc were recorded at stations (4 and 5) witnessing much industrial activities. The concentration of manganese observed at station 5 is approximately 17 folds what was obtained at stations 1, 2, 3 and 3 folds what was observed at station 4 . This high concentration observed at station 5 is attributable to industrial activities (especially bitumen blending because it is the only unique activity) observed at the station. This concentration of manganese observed at station 5 is in conformity with what was obtained by Wogu and Okaka (2011) in Warri River which receives high discharge of effluents from industries. The level of lead obtained from the study stations were at all times beyond World Health Organization recommended maximum concentration $(0.01 \mathrm{mg} / \mathrm{l})$ for portable water. This high concentration of lead observed at all stations signifies intense industrial activities going on along the watershed of the stations and even ahead of the first station. The observed loads of lead in this study are similar to the observation made by Omo-Irabor and Olobaniyi (2007) and Aisien et al. (2010) in their study restricted to the upstream of Benin River. The observed variations in the concentration of nickel observed at the study stations were similar to that recorded in the lead. A sort of homogeneity was observed to exist among the following grouped stations (station 1, 2 and 3); (4 and 5 ), these correlated with the intensity of activities observed at these stations. The order of dominancy of the heavy metal is as follows $\mathrm{Fe}>\mathrm{Zn}>\mathrm{Mn}>\mathrm{Cr}>\mathrm{Ni}>$ $\mathrm{Cu}>\mathrm{Pb}$. High availability of heavy metals in this aquatic body can be attributed to its acidic nature as low $\mathrm{pH}$ could lead to increased leaching of metals and hence higher concentrations in water. High heavy metals concentration observed among the designated sampled spot is of urgent importance; there is need to curb the activities of human that contributes to increase in the concentrations of these elements because of their health implications.

Principal component analyse: The physical and chemical parameters investigated in this research have been used to assess the water quality of some reservoirs at different parts of the world. A strong loading factor was revealed in the first component (PC1) for $\mathrm{Na}, \mathrm{K}$, $\mathrm{Ca}$ and $\mathrm{Mg}$ suggests processes of chemical weathering, mineral dissolution and soil erosion from the watershed (Vega et al., 1998). In this component, increased 
loading of TSS, COD, $\mathrm{Zn}, \mathrm{Pb}$ and Ni reflects an influx of organic pollution and industrial effluent.

Similar to the PC1, PC2 shows strong positive loading of EC, TDS, $\mathrm{Fe}, \mathrm{Cr}, \mathrm{Mn}$ and moderate $\mathrm{Cl}^{-}$represents organic pollution and industrial effluent hence the sampled stations 4 and 5 of the Benin River is very close to oil and gas companies therefore the presence of $\mathrm{Fe}, \mathrm{Mn}, \mathrm{Cr}$ and $\mathrm{Cl}^{-}$can be linked to their activities. PC3 reflects strong loading factor for $\mathrm{NO}_{3}{ }^{-}$and $\mathrm{SO}_{4}{ }^{2-}$ which implies an influx of agricultural chemical fertilizers linked to human activities. PC4 indicates a strong positive loading for BOD and moderate $\mathrm{DO}$, which represents influx of organic pollution and industrial effluent. PC5 has strong negative loading of $\mathrm{pH}$ although with no correlation with heavy metals but suggests organic matter decomposition (Kaizer and Osakwe, 2010). Meanwhile the PC6 shows a strong loading factor for Turbidity representing surface runoff originating from human activities and contains high load of solids arising from waste.

\section{Water quality index of sampling stations}

Increase in WQI values were observed in the sampling station 1, 2, 3 and a drastic rise in station 4 and 5 (Table $3)$. Thus, this progressive increase in WQI values along the Benin River suggests an increase in anthropogenic activities ranging from organic pollution, discharge of poorly treated effluent, agricultural wastes and human activities and correspond with result from PCA and the measured water quality data. Therefore, the water quality at the sampling stations 1 and 3 was very poor for drinking (201 - 300) and station 2, 4 and 5 was unsuitable (> 301) for human consumptions.

Conclusion: This study presents the usefulness of PCA techniques in water quality assessment and pollution source fingerprinting. The results of the PCA reflected anthropogenic activities responsible for water quality variations in the sampled stations of Benin River and was mainly related to organic pollution and industrial effluent (DO, BOD, COD, Turbidity, $\mathrm{Pb}$, and $\mathrm{Ni}$ ) in station 4, inorganic nutrients and industrial pollution $\left(\mathrm{NO}_{3}, \mathrm{PO}_{4}, \mathrm{Zn}, \mathrm{Fe}, \mathrm{Pb}, \mathrm{Ni}\right.$, and $\left.\mathrm{EC}\right)$ in station 5 , while station 1,2 and 3 showed less variability in water quality parameters. WQI results clearly showed that the status of the water body in Benin River was very poor in station 1 and 3, while station 2, 4, and 5 was unsuitable for human uses. It is important to conclude that PCA and WQI are effective tools for understanding the dynamics between anthropogenic influences and water quality status. Therefore, this investigation is a call to action for the state and federal ministry of environment to take this issue of water quality degradation in Benin River into consideration. An intense and continuous water quality monitoring is highly recommended, because if this trend is not discouraged, direct threats to human health and biotic organism is inevitable.

\section{REFERENCES}

Agbaire, P. O., Obi, C. G. (2009). Seasonal Variations of Some Physico-Chemical Properties of River Ethiope Water in Abraka, Nigeria. J. Appl. Sci. Environ. Manage. 13(1): $55-57$.

Aisien, E. T., Das Gbegbaje, .E.I.I and Aisien, F. A. (2010). Water quality assessment of River Ethiope in the NigerDelta coast of Nigeria. Electronic Journal of Environmental, Agricultural and Food Chemistry. 9(11):1739-1745.

Ajayi, S. O. and Osibanjo, O. (1981). Pollution studies on Nigerian Rivers, II: Water quality of some Nigerian Rivers. Environ Pollut Ser. 32: 87-95.

American Public Health Association /American Water Works Association/Water Pollution Control Federation (1998). Standard methods for the examination of water and waste water. 20th Ed. APHA, Washington, DC 1325pp.

Anazawa, K., Kaida, Y., Tomiyasu, T. and Sakamoto (2004). Heavy metal distribution in the river waters and sediments around a 'Firefly Village', Shikoku: Application of multivariate analysis. Analytical Sciences 20: $79-84$.

Arimoro, F. O., Ikomi, R. B and Osalor, E.C. (2006). The Impact of sawmill wood wastes on the water quality and fish communities of Benin River, Niger Delta Area, Nigeria. World Journal of Zoology 1 (2): 94-102.

Ashwani, K. and Anish, D. (2009). Water quality index for assessment of water quality of river Ravi at Madhopur (India). Glob. J. of Envtal Sci. 8 (1): 49 - 57

Chinedu, S. N.; Nwinyi O. C., Oluwadamisi, A. Y., Eze, V. N. (2011). Assessment of water quality in Canaanland, Ota, Southwest Nigeria. Agriculture and Biology Journal of North America. 2 (4): 577-583.

Cude, C. (2001). Oregon water quality index: A tool for evaluating water quality management effectiveness. $J$. Amer. Water Res. Ass., 37, 125-137.

Don-pedro, K. N., Oyewo, E. O. and Otitoloju, A. A. (2004). Trend of heavy metal concentration in Lagos Lagoon ecosystem, Nigeria. West African Journal of Applied Ecology, 5: 103-114.

Edema, C. U. (1993). Heavy metals in shell fishes of Warri river catchments area, Ph.D. Thesis, University of Benin, Benin City, Nigeria.

Egborge, A. B. M. (1991). Industrialization and heavy metal pollution in Warri river. 32nd Inaugural Lecture. University of Benin, Benin City. 
Ezemonye, L. I. N. (1992). Heavy metals concentration in water, sediment and selected fish of Warri river and its tributaries. Ph.D. Thesis, University of Benin, Benin City, Nigeria.

Food and Agricultural Organisation (2007): Coping with water scarcity, 2007 World Water Day, 22nd March, 2007. Available at http://www.fao.org/nr/water. Retrieved $14^{\text {th }}$ February, 2012

Fufeyin, P. (1987). Studies on the fish community of Benin River to evaluate the effects of warm water effluent discharged by NEPA station at Sapele, Bendel state. M. Sc. thesis, University of Benin, Benin City, Nigeria. $101 \mathrm{pp}$.

Kaizer, A. N., Osakwe, S. A. (2010) Physicochemical Characteristics and Heavy Metal Levels in Water Samples from Five River Systems in Delta State, Nigeria. Journal of Appl. Sci. Environ. Manage.14 (1): 83-87.

Liu, C.W.; Lin, K. H.; Kuo, Y. M. (2003) Application of Factor Analysis in the Assessment of Groundwater Quality in a Blackfoot Disease Area in Taiwan. Sci. Total Environ., 313, 77-89.

Moshood, K. M. (2008). Assessment of the water quality of Oyun reservoir, Offa, Nigeria, using selected physicochemical parameters. Turkish Journal of Fisheries and Aquatic Sciences 8: 309-319.

Nigerian Industrial Standard - NIS (2007). Nigerian Standard for Drinking Water Quality. NIS 554. 30pp.

Ogbeibu A. E., Anagboso M. U. (2003/04) Baseline limnological investigation of the Utor River in Esan southeast, Edo state, southern Nigeria: Physical and chemical hydrology. Tropical freshwater biology 12/13: 45-62.

Ogbeibu, A. E. (2011). Oil spill tracking and characterization - Case study of oil pollution in the Ethiope-Benin River, Niger Delta, Nigeria. IAIA Conference, Puebla, Mexico.

Olomukoro, J. O., Egborge, A. B. M. (2003/04). Hydrobiological studies on Warri River, Nigeria. Part II: Seasonal trend in the physic-chemical limnology. Tropical freshwater biology, 12/13:9-23.

Omoigberale, M. O, Ogbeibu, A. E. (2005). Assessing the environmental impacts of oil exploration and production on the Osse river, Southern Nigeria, I. Heavy metals. African Journal of Environmental Pollution and Health 4(1), 27-32.
Omo-Irabor, O O; Olobaniyi, S. B. (2007). Investigation of the Hydrological Quality of Ethiope River Watershed, Southern Nigeria. J. Appl. Sci. Environ. Manage. 11(2): $13-19$.

Onwudinjo, C. C. (1990). The Hydrology and Plankton of Benin River, Nigeria. Ph. D. thesis, University of Benin, Benin City, Nigeria.

Onyeonwu, R. O. (2000). Manual for Waste/Wastewater, Soil/ Sediment, Plant and Fish analysis. MacGill Environmental Research Laboratory Manual. Benin City. $81 \mathrm{pp}$.

Osibanjo,O. Daso A. P., Gbadebo A. M. (2011) The impact of industries on surface water quality of River Ona and River Alaro in Oluyole Industrial Estate, Ibadan, Nigeria. Afr. J. Biotechno. 10 (4): 696-702.

Radajevic, M and Bashkin V. N. (1999). Practical environmental analysis. Royal school of chemistry, Thomas Graham house, science park Cambridge, UK. 645pp.

Ramakrishniah, C. R., Sadashivaiah, C. and Ranganna, G. (2009). Assessment of Water Quality Index for the Groundwater in Tumkur Taluk. E-J. of Chem. 6(2), 523530 .

Tepe, Y. and Mutlu, E. (2005). Physico-chemical characteristics of Hatay Harbiye Spring water.

United Nations Environment Programme (2006). Water quality for ecosystem and human health. Published by the United Nations Environment Programme Global Environment Monitoring System (GEMS)/Water Programme. 132pp

Velz, C. J. (1985). Applied stream sanitation. Wiley intrascience. New York.

Vega M, Parda R, Barrada E, Deban L., (1998). Assessment of seasonal and polluting effects on the quality of river water by exploratory data analysis. Water Res. 32: 35813592.

Wayne, G. L, Ming-Ho, Y. (2005). Introduction to environmental toxicology. CRC Press LLC, Boca Raton, Florida. 484pp.

Wogu, M. D., Okaka, C. E. (2011) Pollution studies on Nigerian rivers: heavy metals in surface water of warri river, Delta State. Journal of Biodiversity and Environmental Sciences. 1(3);7-12. 